\title{
THE TAUTOMERISM OF PYRAZOLINES (DIHYDROPYRAZOLES)
}

\author{
I. ALKORTA* AND J. ELGUERO \\ Instituto de Química Médica (CSIC), Juan de la Cierva, 3, E-28006 Madrid, Spain \\ Dedicated to Professor Josep Castells on the occasion of his $90^{\text {th }}$ Birthday
}

\begin{abstract}
The exception to the rule that $\Delta^{3}$-pyrazolines are not stable unless both nitrogen atoms are substituted that has been recently published, Tetrahedron Lett. $\mathbf{5 5}, 2208$, (2014), has been proved false. By means of GIAO/B3LYP/6-311++G(d,p) calculations, it has been shown that the product is a pyrazole formed by rearrangement.
\end{abstract}

Keywords: pyrazolines, dihydropyrazoles, rearrangement, NMR, DFT calculations, GIAO

\section{INTRODUCTION}

There exists a clear imbalance in tautomeric studies of heterocycles between the much studied aromatic compounds and the seldom studied non-aromatic compounds. A clear example is the pyrazole/pyrazoline pair. There are hundreds of publications dealing with pyrazoles, ${ }^{1,2}$ while there is only one paper where a theoretical study of the tautomerism of pyrazolines (dihydropyrazoles) is reported. ${ }^{3}$ This is not due to the relative importance of both heterocycles, at least, not only, but more probably to the fact that pyrazole tautomers have similar energies while in the case of pyrazoline one tautomer is clearly more stable than the others. Pyrazolinones (pyrazolones) occupy an intermediate situation having both aromatic and non-aromatic tautomers, and they have been also much studied. ${ }^{1,4}$

According to our calculations carried out at the B3LYP/6-311++G(d,p) level for compounds $\mathbf{1 a}-\mathbf{1} \mathbf{c},{ }^{3}$ that we have completed for the present work for compounds $\mathbf{2 b}$-2d (Scheme 1), the $\Delta^{2}$-pyrazolines (4,5-dihydro- $1 H$-pyrazoles, $\mathbf{1 b}$ and $\mathbf{2 b})$ are more stable than the $\Delta^{1}$-pyrazolines $(4,5$-dihydro- $3 H$-pyrazoles, 1a). By far, the $\Delta^{3}$-pyrazolines (2,3-dihydro- $1 H$-pyrazoles, 1c, 2c, 2d) are the less stable. It is interesting to note that the methyl group stabilizes the $\Delta^{3}$ tautomers.<smiles>C1CN=NC1</smiles>

1a: 8.5<smiles>C1=NNCC1</smiles>

1b: 0.0<smiles>CN1CCC=N1</smiles>

2b: 0.0<smiles>C1=CNNC1</smiles>

1c: 83.1<smiles>CN1CC=CN1</smiles>

2c: 63.1<smiles>CN1C=CCN1</smiles>

2d: 60.8
Scheme 1. The different pyrazolines and their relative energies in $\mathrm{kJ} \cdot \mathrm{mol}^{-1}$.

Pyrazolines tautomerize one into another by mere heating and by acid catalysis. Thus 1 -unsubstituted $\Delta^{2}$-pyrazolines, like $\mathbf{1 b}$, thermally isomerizes into $\Delta^{1}$-pyrazolines, like 1a, that lose $N_{2}$ to yield cyclopropanes. ${ }^{5}$ The $\Delta^{1}$ to $\Delta^{2}$ isomerization is also known. ${ }^{6}$

$\mathrm{N}_{1}-\mathrm{H}$ or $\mathrm{N}_{2}-\mathrm{H} \Delta^{3}$-pyrazolines $(\mathbf{1 c}, \mathbf{2 c}, \mathbf{2 d})$ are so unstable that they are not isolated and transform spontaneously into $\Delta^{2}$-pyrazolines $(\mathbf{1 b}, \mathbf{2 b})$ and, with some exceptions, only 1,2-disubstituted $\Delta^{3}$-pyrazolines are known.

In 1970, Wittig and Hutchison, ${ }^{7}$ reported the following sequence of reactions $\left(\mathbf{3} \rightarrow \mathbf{4} \rightarrow \mathbf{5}\right.$, Scheme 2 ) where a $\mathrm{N}_{1}-\mathrm{H} \Delta^{3}$-pyrazoline $\mathbf{5}$ was isolated.

We demonstrated afterwards that the product of rearrangement of the pyrazolenine 3 was not the pyrazole 4 but the isopyrazole 6 that was reduced by lithium aluminium hydride to a $\Delta^{2}$-pyrazoline 7 , therefore disproving an example of $\mathrm{N}_{1}-\mathrm{H} \Delta^{3}$-pyrazoline stable. However, we described that these compounds could be stable when they carry special substituents (Scheme 3 ). ${ }^{8}$

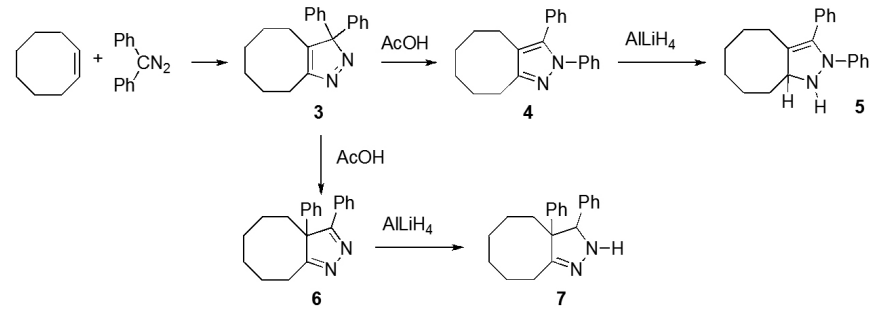

Scheme 2. Formation of a $\Delta^{2}$-pyrazoline 7 and not of a $\Delta^{3}$-pyrazoline $\mathbf{5}$.

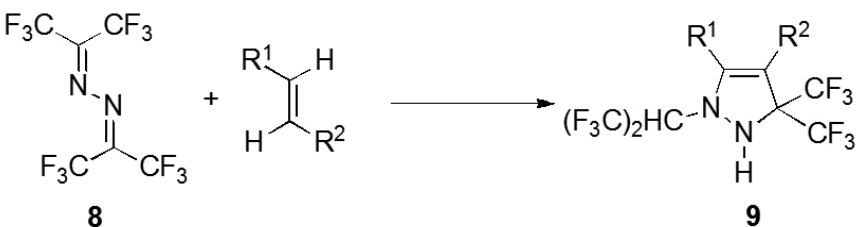

Scheme 3. The structure of a true $\mathrm{N}_{1}-\mathrm{H} \Delta^{3}$-pyrazoline.

When hexafluoroacetone azine $(\mathbf{8})$ reacted with one alkene, compound 9 was isolated. The presence of a geminal trifluoromethyl group at position 5 prevented the isomerization of 9 to a $\Delta^{2}$-pyrazoline. ${ }^{8}$

The situation seemed clear until recently a counterexample was published.

\section{RESULTS AND DISCUSSION}

In 2009, Ashton T. Hamme II and co-workers published a paper that contains the following sequence (Scheme 4). When 2-methylene-1,3,3trimethylindoline (10) reacts with a nitrile imine (generated in situ from 11a) a spiro- $\Delta^{2}$-pyrazoline 12a was formed that rearranged into the pyrazole 13a (characterized by X-ray crystallography: Figure 1, refcode CORTEJ). ${ }^{9}$ The authors propose that the rearrangement involves the $\Delta^{3}$-pyrazoline 14a. ${ }^{10}$

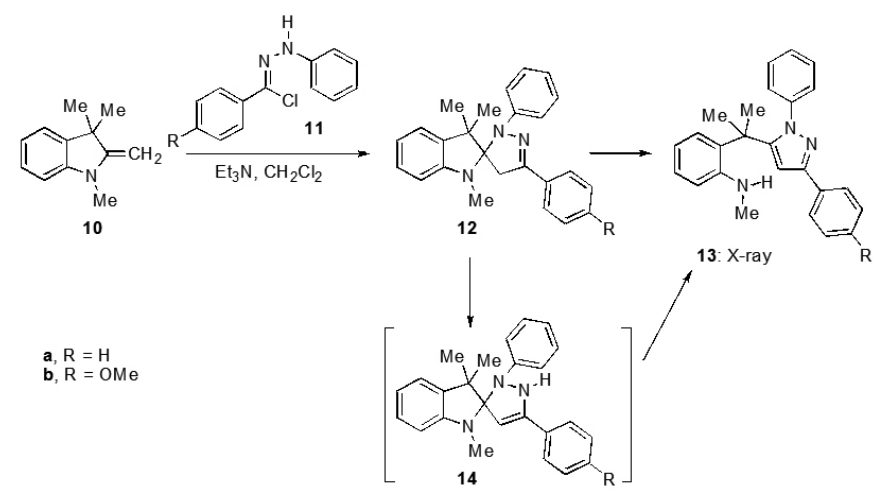

Scheme 4. Hamme's results of 2009. 

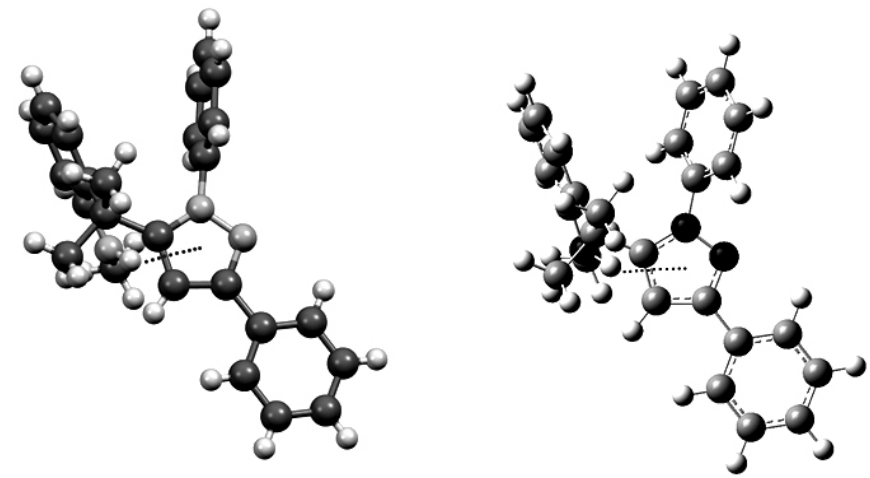

Figure 1. Left side: $\mathrm{X}$-ray structure of 2-(2-1,3-diphenyl-1H-pyrazol-5yl)-N-methylaniline (13a).$^{10}$ Right side: optimized B3LYP/6-311++G(d,p) structure of 13a.

The X-ray structure shows a $\mathrm{N}-\mathrm{H} \cdots \pi$ hydrogen bond involving the aromatic electrons of the pyrazole ring. They also reported the ${ }^{1} \mathrm{H}$ and ${ }^{13} \mathrm{C}$ chemical shifts but without assigning them. We have used the atom numbering of Scheme 5 to prepare Table 1 where a tentative assignment was made using GIAO/B3LYP/6-311++G(d,p) calculated chemical shifts (see Computational Methods).

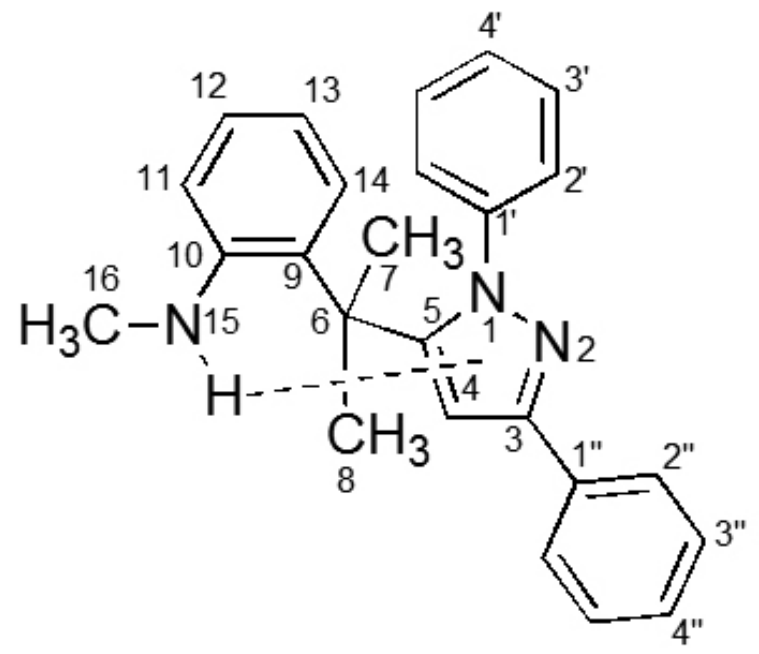

Scheme 5. Atom numbering of pyrazole 13a.

In 2014, the same authors published for $\mathrm{R}=\mathrm{OMe}$, the study of the equilibrium $\mathbf{1 2 b} / \mathbf{1 4} \mathbf{b} .{ }^{11}$ They reported the X-ray structure of $\mathbf{1 2 b}$, but the CCDC deposition number 701051 actually corresponds to 13a although the Figure that appears in their paper is that of $\mathbf{1 2} \mathbf{b}$. They described the properties of both tautomers that depend on the solvent: in benzene (12b, yellow solution) and in chloroform (14b, pink solution). They used trifluoroacetic acid (TFAA) to transform tautomer $\mathbf{1 2 b}$ into tautomer $\mathbf{1 4 b}$ (Scheme 6). The latter one was stable in these conditions.

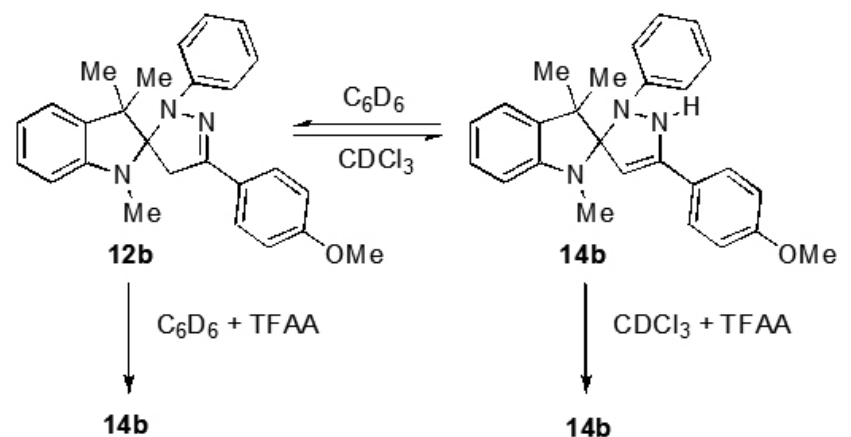

Scheme 6. Equilibrium $12 \mathrm{~b} / \mathbf{1 4 b}$ and protonated pyrazolinium salts. 13a.

Table 1: Calculated and experimental chemical shifts (ppm) of compound

\begin{tabular}{|c|c|c|c|}
\hline Atom & Calculated & Experimental & Notes \\
\hline \multicolumn{4}{|c|}{${ }^{1} \mathrm{H}$ NMR } \\
\hline $\mathrm{H} 4$ & 6.76 & 6.80 & under the $6.79-6.82 \mathrm{~m}, 3 \mathrm{H}$ \\
\hline $\mathrm{H} 2^{\prime}$ & 6.78 & 6.67 & $\mathrm{~d}, 2 \mathrm{H}, J=8 \mathrm{~Hz}$ \\
\hline H3 & 7.04 & 7.07 & under the $7.07 \mathrm{q}, 3 \mathrm{H}$ \\
\hline $\mathrm{H} 4{ }^{\prime}$ & 7.25 & 7.19 & $\mathrm{t}, 1 \mathrm{H}, J=7.5 \mathrm{~Hz}$ \\
\hline $\mathrm{H} 2 "$ & 8.00 & 7.91 & $\mathrm{~d}, 2 \mathrm{H}, J=7 \mathrm{~Hz}$ \\
\hline H3" & 7.32 & 7.39 & under the $7.33-7.46 \mathrm{~m}, 3 \mathrm{H}$ \\
\hline $\mathrm{H} 4 ”$ & 7.14 & 7.07 & under the $7.07 \mathrm{q}, 3 \mathrm{H}$ \\
\hline $\mathrm{Me} 7$ & 1.52 & 1.68 & $\mathrm{~s}, 3 \mathrm{H}$ \\
\hline Me8 & 1.52 & 1.68 & $\mathrm{~s}, 3 \mathrm{H}$ \\
\hline H11 & 6.54 & 6.52 & $\mathrm{~d}, 1 \mathrm{H}, J=7.5 \mathrm{~Hz}$ \\
\hline H12 & 7.31 & 7.39 & under the $7.33-7.46 \mathrm{~m}, 3 \mathrm{H}$ \\
\hline H13 & 6.52 & 6.40 & $\mathrm{t}, 1 \mathrm{H}, J=7.5 \mathrm{~Hz}$ \\
\hline H14 & 6.75 & 6.80 & under the $6.79-6.82 \mathrm{~m}, 3 \mathrm{H}$ \\
\hline NH15 & 4.49 & 4.15 & $1 \mathrm{H}$, broad singlet \\
\hline Me16 & 2.56 & 2.71 & $3 \mathrm{H}$ \\
\hline \multicolumn{4}{|c|}{${ }^{13} \mathrm{C}$ NMR } \\
\hline $\mathrm{C} 3$ & 150.2 & 150.9 & \\
\hline $\mathrm{C} 4$ & 100.9 & 101.0 & \\
\hline $\mathrm{C} 5$ & 152.9 & 153.0 & \\
\hline $\mathrm{C} 1{ }^{\prime}$ & 143.1 & 140.3 & \\
\hline $\mathrm{C} 2{ }^{\prime}$ & 129.3 & 128.9 & \\
\hline $\mathrm{C} 3{ }^{\prime}$ & 127.2 & 128.1 & \\
\hline $\mathrm{C} 4{ }^{\prime}$ & 127.8 & 128.3 & \\
\hline $\mathrm{C} 1 "$ & 134.4 & 133.3 & \\
\hline $\mathrm{C} 2 "$ & 124.9 & 126.0 & \\
\hline C3" & 128.0 & 128.2 & \\
\hline $\mathrm{C} 4 "$ & 126.9 & 128.1 & \\
\hline C6 & 42.8 & 38.0 & \\
\hline $\mathrm{Me} 7$ & 27.1 & 28.9 & \\
\hline $\mathrm{Me} 8$ & 27.1 & 28.9 & \\
\hline $\mathrm{C} 9$ & 131.8 & 129.4 & \\
\hline $\mathrm{C} 10$ & 148.0 & 147.2 & \\
\hline C11 & 109.3 & 110.8 & \\
\hline $\mathrm{C} 12$ & 128.2 & 128.7 & \\
\hline $\mathrm{C} 13$ & 115.7 & 116.8 & \\
\hline $\mathrm{C} 14$ & 126.1 & 125.9 & \\
\hline Me16 & 28.5 & 31.1 & \\
\hline \multicolumn{4}{|c|}{${ }^{15} \mathrm{~N}$ NMR } \\
\hline N1 & -163.9 & ---- & \\
\hline N2 & -64.7 & ---- & \\
\hline N15 & -324.3 & ---- & \\
\hline
\end{tabular}

The results reported in Scheme 6 are in total contradiction to what we have summarized in the introduction. We have calculated at the B3LYP/6$311++G(d, p)$ level the energies of the compounds of Scheme 6 (Table 2). 
Table 2: Energies (hartrees) and relative energies $\left(\mathrm{kJ} \cdot \mathrm{mol}^{-1}\right)$ of the compounds of Scheme 5 .

\begin{tabular}{|c|c|c|c|c|}
\hline Compound & SCF Energy & ZPE & Total Energy & $E_{\text {rel }}$ \\
\hline $\mathbf{1 2 b}$ & -1246.7844 & 0.47710 & -1245.9917 & 0.0 \\
\hline $\mathbf{1 4 b}$ & -1246.7655 & 0.47689 & -1245.9688 & 49.7 \\
\hline
\end{tabular}

It is clear that, consistently with our previous calculations (Scheme 1), a solvent effect cannot account for the existence of $\mathbf{1 4 b}$ in chloroform.

We have calculated the absolute shieldings of the compounds of Table 1 $(\sigma, \mathrm{ppm})$ at the GIAO/B3LYP/6-311++G(d,p) level and transformed them into chemical shifts $(\delta, \mathrm{ppm})$ by means of empirical equations we have established previously (see Computational Methods).

We will first discuss the case of $\mathbf{1 2 b}$ because there is no doubt about its structure. Unfortunately, the authors reported its chemical shifts without assignment and with only the number of protons and some coupling $J_{\mathrm{HH}}$ values, that we have used to build up Table 3 using the numbering of Scheme 7.

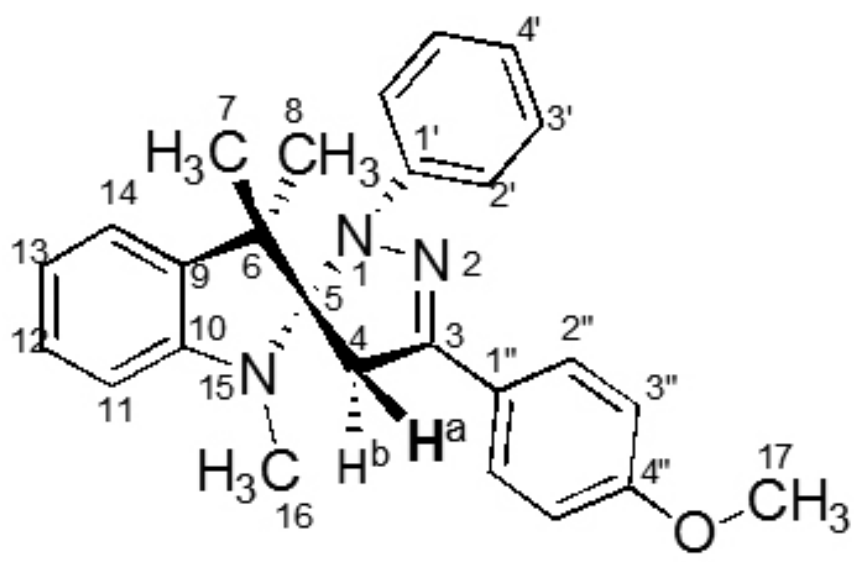

Scheme 7. Numbering of $\mathbf{1 2 b}$ used for NMR. Methyl 7 is close to C4 and the methyl 8 is close to the N1-phenyl group; $\mathrm{H}^{\mathrm{a}}$ is close to $\mathrm{C} 6$ and $\mathrm{H}^{\mathrm{b}}$ is close to N15.

The assignment was done by analogy and some errors between close signals are possible. That of Table 3 corresponds to Exp. $=(1.002 \pm 0.003)$ Calcd., $\mathrm{n}=37, \mathrm{R}^{2}=0.999$.

In Table 4 we have reported the other compound of Table 1 , the $\Delta^{3}$ pyrazoline $\mathbf{1 4 b}$ while its numbering is in Scheme 8 .

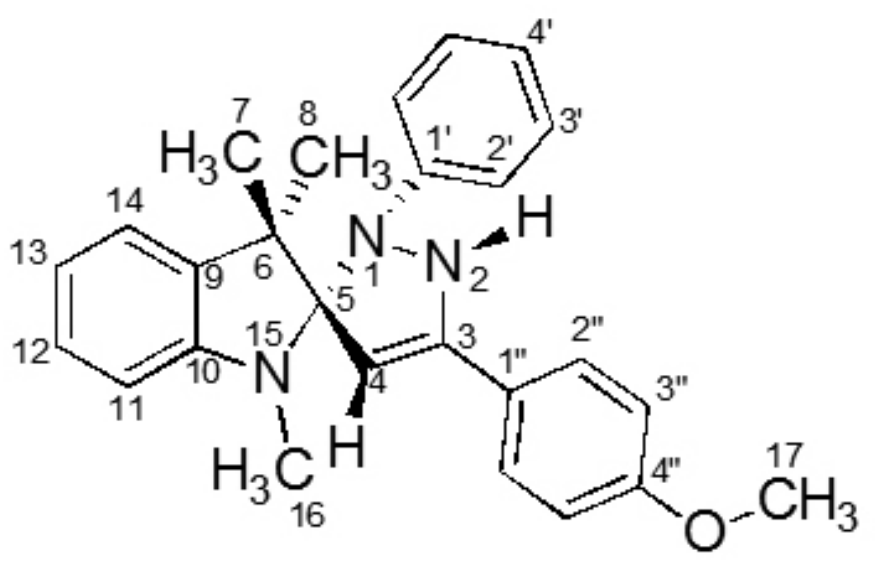

Scheme 8. Numbering of $\mathbf{1 4 b}$ used for NMR the methyl 8 is close to the N1-phenyl group.
Table 3: Calculated and experimental chemical shifts (ppm) of compound $12 b$

\begin{tabular}{|c|c|c|c|}
\hline Atom & Calculated & Experimental & $\begin{array}{l}\text { multiplicity, number of } \\
\text { protons and } J_{\text {. }}\end{array}$ \\
\hline \multicolumn{4}{|c|}{${ }^{1} \mathrm{H}$ NMR } \\
\hline $\mathrm{H} 4^{\mathrm{a}}$ & 3.75 & 3.40 & $\mathrm{~d}, 1 \mathrm{H}, J=18.2 \mathrm{~Hz}$ \\
\hline $\mathrm{H} 4^{\mathrm{b}}$ & 3.23 & 3.03 & $\mathrm{~d}, 1 \mathrm{H}, J=18.2 \mathrm{~Hz}$ \\
\hline $\mathrm{H} 2{ }^{\prime}$ & 7.07 & 7.03 & $\mathrm{~m}$ \\
\hline H3 & 6.92 & 6.94 & $\mathrm{~m}$ \\
\hline $\mathrm{H} 4{ }^{\prime}$ & 6.61 & 6.73 & $\mathrm{t}, 1 \mathrm{H}, J=7.3 \mathrm{~Hz}$ \\
\hline $\mathrm{H} 2 "$ & 7.84 & 7.72 & $\mathrm{~d}, 2 \mathrm{H}, J=8.8 \mathrm{~Hz}$ \\
\hline H3" & 6.82 & 6.76 & $\mathrm{~m}$ \\
\hline $\mathrm{Me} 7$ & 1.35 & 1.10 & $\mathrm{~s}, 3 \mathrm{H}$ \\
\hline Me8 & 1.38 & 1.29 & $\mathrm{~s}, 3 \mathrm{H}$ \\
\hline H11 & 6.03 & 6.09 & $\mathrm{~d}, 1 \mathrm{H}, J=7.6 \mathrm{~Hz}$ \\
\hline $\mathrm{H} 12$ & 7.12 & 7.22 & $\mathrm{~m}$ \\
\hline H13 & 6.87 & 6.76 & $\mathrm{~m}$ \\
\hline H14 & 7.10 & 7.22 & $\mathrm{~m}$ \\
\hline Me16 & 2.27 & 2.25 & $\mathrm{~s}, 3 \mathrm{H}$ \\
\hline Me17 & 3.70 & 3.32 & $\mathrm{~s}, 3 \mathrm{H}$ \\
\hline \multicolumn{4}{|c|}{${ }^{13} \mathrm{C}$ NMR } \\
\hline $\mathrm{C} 3$ & 142.3 & 141.8 & \\
\hline $\mathrm{C} 4$ & 41.9 & 39.8 & \\
\hline $\mathrm{C} 5$ & 102.5 & 100.6 & \\
\hline C6 & 52.6 & 55.1 & \\
\hline $\mathrm{Me} 7$ & 32.2 & 31.3 & \\
\hline Me8 & 30.8 & 29.1 & \\
\hline C9 & 135.2 & 141.8 & \\
\hline $\mathrm{C} 10$ & 150.9 & 150.8 & \\
\hline $\mathrm{C} 11$ & 103.3 & 104.8 & \\
\hline $\mathrm{C} 12$ & 128.6 & 129.8 & \\
\hline $\mathrm{C} 13$ & 117.8 & 114.6 & \\
\hline $\mathrm{C} 14$ & 122.1 & 120.8 & \\
\hline Me16 & 27.1 & 29.1 & \\
\hline $\mathrm{C} 1$ ' & 145.5 & 147.3 & \\
\hline $\mathrm{C} 2{ }^{\prime}$ & 116.4 & 118.6 & \\
\hline C3' & 128.2 & 127.5 & \\
\hline C4' & 118.6 & 118.8 & \\
\hline $\mathrm{C} 1 "$ & 126.8 & 126.2 & \\
\hline $\mathrm{C} 2 "$ & 126.1 & 121.8 & \\
\hline C3" & 112.7 & 114.6 & \\
\hline $\mathrm{C} 4 "$ & 160.4 & 160.8 & \\
\hline Me17 & 52.8 & 55.1 & \\
\hline \multicolumn{4}{|c|}{${ }^{15} \mathrm{~N}$ NMR } \\
\hline N1 & -200.6 & --- & \\
\hline N2 & -54.2 & --- & \\
\hline N15 & -291.7 & --- & \\
\hline
\end{tabular}


Table 4: Calculated and experimental chemical shifts (ppm) of compound 14b.

\begin{tabular}{|c|c|c|c|c|}
\hline Atom & Calcd. 14b & Calcd. 13b & Exp. & multiplicity, no. of protons and $J_{\mathrm{HH}}$ \\
\hline \multicolumn{5}{|c|}{${ }^{1} \mathrm{H}$ NMR } \\
\hline $\mathrm{NH} 2$ & 4.55 & --- & ---- & broad singlet, $1 \mathrm{H}$ \\
\hline $\mathrm{H} 4$ & 4.87 & 6.59 & 6.72 & $\mathrm{~s}, 1 \mathrm{H}$ \\
\hline $\mathrm{H} 2^{\prime}$ & 6.91 & 6.76 & 6.66 & $\mathrm{~d}, 1 \mathrm{H}, J=8 \mathrm{~Hz}$ \\
\hline H3 & 6.95 & 7.04 & & under $6.93-7.21 \mathrm{~m}$ \\
\hline H4' & 6.63 & 7.25 & & under $6.93-7.21 \mathrm{~m}$ \\
\hline $\mathrm{H} 2 ”$ & 7.70 & 7.92 & 7.82 & $\mathrm{~d}, 2 \mathrm{H}, J=8.8 \mathrm{~Hz}$ \\
\hline H3" & 6.85 & 6.76 & & under $6.93-7.21 \mathrm{~m}$ \\
\hline $\mathrm{Me} 7$ & 1.39 & 1.48 & 1.67 & $\mathrm{~s}, 3 \mathrm{H}$ \\
\hline $\mathrm{Me} 8$ & 1.37 & 1.48 & 1.67 & $\mathrm{~s}, 3 \mathrm{H}$ \\
\hline H11 & 5.92 & 6.57 & 6.51 & $\mathrm{~d}, 1 \mathrm{H}, J=8 \mathrm{~Hz}$ \\
\hline H12 & 7.04 & 7.27 & & under $6.93-7.21 \mathrm{~m}$ \\
\hline H13 & 6.71 & 6.51 & 6.39 & $\mathrm{t}, 1 \mathrm{H}, J=7.8 \mathrm{~Hz}$ \\
\hline H14 & 7.12 & 6.75 & 6.79 & $\mathrm{~d}, 1 \mathrm{H}, J=7.8 \mathrm{~Hz}$ \\
\hline NH15 & ---- & 4.46 & 4.14 & broad singlet, $1 \mathrm{H}$ \\
\hline Me16 & 2.13 & 2.56 & 2.70 & $\mathrm{~d}, 3 \mathrm{H}, J=5 \mathrm{~Hz}$ \\
\hline Me17 & 3.72 & 3.66 & 3.85 & $\mathrm{~s}, 3 \mathrm{H}$ \\
\hline \multicolumn{5}{|c|}{${ }^{13} \mathrm{C}$ NMR } \\
\hline $\mathrm{C} 3$ & 147.3 & 150.0 & 150.7 & \\
\hline $\mathrm{C} 4$ & 98.4 & 100.1 & 100.6 & \\
\hline $\mathrm{C} 5$ & 109.2 & 152.3 & 152.8 & \\
\hline C6 & 55.2 & 42.6 & 38.1 & \\
\hline $\mathrm{Me} 7$ & 29.0 & 27.2 & 28.9 & \\
\hline Me8 & 22.1 & 27.2 & 28.9 & \\
\hline C9 & 136.1 & 131.6 & 129.5 & \\
\hline $\mathrm{C} 10$ & 151.4 & 147.7 & 147.3 & \\
\hline $\mathrm{C} 11$ & 102.7 & 109.4 & 110.7 & \\
\hline $\mathrm{C} 12$ & 128.4 & 128.3 & 128.2 & \\
\hline $\mathrm{C} 13$ & 116.6 & 115.9 & 116.7 & \\
\hline $\mathrm{C} 14$ & 121.7 & 126.3 & 126.1 & \\
\hline Me16 & 26.6 & 28.5 & 31.1 & \\
\hline $\mathrm{C} 1^{\prime}$ & 148.0 & 143.5 & 140.4 & \\
\hline $\mathrm{C} 2{ }^{\prime}$ & 116.2 & 129.4 & 128.7 & \\
\hline $\mathrm{C} 3{ }^{\prime}$ & 127.9 & 127.0 & 128.1 & \\
\hline $\mathrm{C} 4^{\prime}$ & 118.2 & 127.6 & 128.2 & \\
\hline $\mathrm{C} 1 "$ & 123.9 & 126.4 & 127.2 & \\
\hline $\mathrm{C} 2 "$ & 127.3 & 125.8 & 125.9 & \\
\hline C3" & 113.3 & 110.8 & 114.3 & \\
\hline C4" & 161.2 & 160.2 & 159.8 & \\
\hline Me17 & 52.8 & 53.1 & 55.6 & \\
\hline \multicolumn{5}{|c|}{${ }^{15} \mathrm{~N} N M R$} \\
\hline N1 & -248.6 & -165.6 & --- & \\
\hline N2 & -254.6 & -68.1 & --- & \\
\hline N15 & -297.5 & -324.6 & --- & \\
\hline
\end{tabular}

It is clear that the experimental values do not correspond to $\mathbf{1 4 b}$. Besides, there is an important experimental ${ }^{1} \mathrm{H}$ NMR datum: the N-Me group at 2.70 ppm is a doublet with $J=5 \mathrm{~Hz}$, this is typical of a NHMe; $;{ }^{12}$ Obviously the compound is the pyrazole 13b [13b and $\mathbf{1 4 b}$ have the same mass $\left(\mathrm{C}_{26} \mathrm{H}_{27} \mathrm{~N}_{3} \mathrm{O}\right)$ ]. It differs from pyrazole 13a in the fact that the coupling between the methyl group Me16 and the $\mathrm{NH}\left(\mathrm{a}^{3} J_{\mathrm{HH}}\right)$ is only observed for the second one, but it is known that observing these couplings depends on the exchange rate of the amino proton. ${ }^{13}$ The calculated chemical shifts for pyrazole $\mathbf{1 3 b}$ (Scheme 8 ) are also reported in Table 4.

Using all the available data of Tables 1 and 4 for the pyrazoles 13a and 13b an excellent correlation is found: Exp. $=(1.000 \pm 0.003)$ Calcd., $\mathrm{n}=69, \mathrm{R}^{2}$ $=0.9998$. Note that the $15_{\mathrm{N}}$ chemical shifts are very different for compounds 13b and 14b.

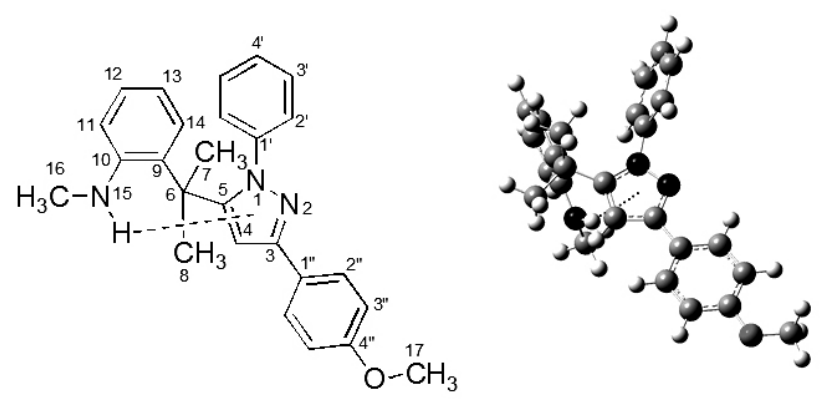

Scheme 9. Left side: Atom numbering of pyrazole 13b. Right side: optimized B3LYP/6-311++G(d,p) structure of $\mathbf{1 3 b}$. 


\section{CONCLUSIONS}

The availability of standard theoretical calculations of absolute shieldings ( $\sigma, \mathrm{ppm})$ and the robustness of the empirical equations to transform them into chemical shifts $(\delta, \mathrm{ppm})$ has allowed to correct an structural error of the literature, ${ }^{11}$ and confirm that $\Delta^{3}$-pyrazolines are stable only when both $\mathrm{N}$ atoms are substituted.

\section{Computational Methods}

DFT calculations were carried out using the $\mathrm{B}^{2} \mathrm{LYP}^{13}$ functional, together with the $6-311++\mathrm{G} / \mathrm{d}, \mathrm{p}$ ) basis set. ${ }^{14}$ Absolute shieldings were calculated within the GIAO approximation. All the calculations were carried out using the Gaussian 09 package. ${ }^{15}$ Empirical equations were used to transform the ${ }^{1} \mathrm{H},{ }^{13} \mathrm{C}$ and ${ }^{15} \mathrm{~N}$ absolute shieldings into chemical shifts. ${ }^{16}$

\section{ACKNOWLEDGMENTS}

This work has been supported by the Spanish Ministerio de Economía y Competitividad (CTQ2012-35513-C02-02) and Comunidad Autónoma de Madrid (S2013/MIT-2841, Fotocarbon). Computer, storage and other resources from the CTI (CSIC) are gratefully acknowledged.

\section{REFERENCES}

1.- (a) J. Elguero, C. Marzin, A. R. Katritzky, P. Linda, The Tautomerism of Heterocycles, Academic Press, New York, 1976. (b) V. I. Minkin, A. D. Garnovskii, J. Elguero, A. R. Katritzky, O. V. Denisko, Adv. Heterocycl. Chem. 76, 157, (2000).

2.- M. Á. García, P. Cabildo, R. M. Claramunt, E. Pinilla, M. R. Torres, I. Alkorta, J. Elguero, Inorg. Chim. Acta 363, 1332, (2010).

3.- F. Blanco, D. G. Lloyd, L. M. Azofra, I. Alkorta, J. Elguero, Struct. Chem. 24, 421, (2013).

4.- C. Trujillo, G. Sánchez-Sanz, I. Alkorta, J. Elguero Chem. Phys. Chem, 2015 in press. Doi 10.1002/cphc. 201500317.

5.- (a) W. M. Jones, J. Am. Chem. Soc. 80, 6687, (1958). (b) W. M. Jones, $J$. Am. Chem. Soc. 81, 3776, (1959). (c) W. M. Jones, J. Am. Chem. Soc. 81, 5153, (1959). (d) W. M. Jones, J. Am. Chem. Soc. 82, 3136, (1960).

6.- (a) J. Bastus, J. Castells, Proc. Chem. Soc. (London) 216, (1962). (b) I. Tabuchi, K. Takagi, R. Oda, Tetrahedron Lett. 5, 2075, (1964). (c) D. T. Witiak, B. K. Sinha, J. Org. Chem. 35, 501, (1970).
7.- G. Wittig, J. J. Hutchison, Ann. Chem. 741, 89, (1970).

8.- (a) K. Burger, H. Schickaneder, J. Elguero, Tetrahedron Lett. 16, 2911, (1975). (b) K. Burger, H. Schickaneder, F. Hein, J. Elguero, Tetrahedron 31, 389, (1979)

9.- (a) F. H. Allen, Acta Crystallogr. B58, 380-388, (2002), (b) CSD version 5.36 (November 2014).

10.- S. Dadiboyena, E. J. Valente, A. T. Hamme II, Tetrahedron Lett. 50, 291, (2009).

11.- S. Dadiboyena, E. J. Valente, A. T. Hamme II, Tetrahedron Lett. 55, 2208, (2014).

12.- (a) I. Alkorta, J. Elguero, Theor. Chem. Acta 111, 31, (2004). (b) S. C. Lim, B. M. Paterson, M. T. Fodero-Tavoletti, G. J. O'Keefe, R. Cappai, K. J. Barhham, V. L. Villemagne, P. S. Donnelly, Chem. Commun. 46, 5437, (2010).

13.- (a) A. D. Becke, J. Chem. Phys. 98, 5648, (1993). (b) C. Lee, W. Yang, R. G. Parr, Phys. Rev. B 37, 785, (1988). (c) B. Miehlich, A. Savin, H. Stoll, H. Preuss, Chem. Phys. Lett. 157, 200, (1989).

14.- (a) R. Ditchfield, W. J. Hehre, J. A. Pople, J. Chem. Phys. 54, 724, (1971). (b) M. J. Frisch, J. A. Pople, J. S. Binkley, J. Chem. Phys. 80, 3265, (1984).

15.- M. J. Frisch, G. W. Trucks, H. B. Schlegel, G. E. Scuseria, M. A. Robb, J. R. Cheeseman, G. Scalmani, V. Barone, B. Mennucci, G. A. Petersson, H. Nakatsuji, M. Caricato, X. Li, H. P. Hratchian, A. F. Izmaylov, J. Bloino, G. Zheng, J. L. Sonnenberg, M. Hada, M. Ehara, K. Toyota, R. Fukuda, J. Hasegawa, M. Ishida, T. Nakajima, Y. Honda, O. Kitao, H. Nakai, T. Vreven, J. A. Montgomery, Jr., J. E. Peralta, F. Ogliaro, M. Bearpark, J. J. Heyd, E. Brothers, K. N. Kudin, V. N. Staroverov, R. Kobayashi, J. Normand, K. Raghavachari, A. Rendell, J. C. Burant, S. S. Iyengar, J. Tomasi, M. Cossi, N. Rega, J. M. Millam, M. Klene, J. E. Knox, J. B. Cross, V. Bakken, C. Adamo, J. Jaramillo, R. Gomperts, R. E. Stratmann, O. Yazyev, A. J. Austin, R. Cammi, C. Pomelli, J. W. Ochterski, R. L. Martin, K. Morokuma, V. G. Zakrzewski, G. A. Voth, P. Salvador, J. J. Dannenberg, S. Dapprich, A. D. Daniels, Ö. Farkas, J. B. Foresman, J. V. Ortiz, J. Cioslowski and D. J. Fox, Gaussian 09, Revision A.1, Gaussian, Inc., Wallingford CT, 2009.

16.- (a) A. M. S. Silva, R. M. S. Sousa, M. L. Jimeno, F. Blanco, I. Alkorta, J. Elguero Magn. Reson. Chem. 46, 859, (2008). (b) F. Blanco, I. Alkorta, J. Elguero, Magn. Reson. Chem. 45, 797, (2007). 